\title{
Challenges and prospects of "green" marketing use by the Russian agricultural producers
}

\author{
Julia Denisenko ${ }^{1}$, Valery Lisitsin ${ }^{1 *}$, and Anna Fedosenko ${ }^{1}$ \\ ${ }^{1}$ Don State Technical University, 1, Gagarina sq., 344003, Rostov-on-Don, Russia
}

\begin{abstract}
The key aspects and specificity of "green" marketing in comparison with the traditional marketing concept along with the areas of environmental activity of agricultural organizations and farms are discussed in the article. The results of the study conducted with the participation of marketing departments' representatives of agricultural organizations of the Southern Federal District are presented in the paper. The research made it possible to identify the main challenges for organic agriculture development and use of "green" marketing tools in the activities of agricultural enterprises. Based on the discussion of the study results as well as on the analysis of scientific literature on the development of "green" marketing and organic agriculture, the directions of Russian agricultural organizations' activity are suggested, which can contribute to the use of "green" marketing tools and improvement of business environmental friendliness, taking into account current global trends of sustainable development and corporate social responsibility.
\end{abstract}

\section{Introduction}

At present, the organic food market is one of the fastest growing segments of the food sector throughout the world. An increase in demand for organic food products is observed every year in Russia, which defines new requirements for food producers with regard to ensuring the focus on "green" production by various means.

The matter of the concept of "green" (environmental) marketing, including its tools and strategies, are discussed in some detail in the works of a number of foreign and Russian authors (Bhalerao S.A., Durmaz Y., Giannetto C., Krakovetskaia I., Lanfranchi M., Polonsky M.J., Rotondo F., Sarkar A.N., Teo Y.V., Yazdanifard R., Zaharova T., Zaitseva D. and others). The emergence and development of the concept of "green" marketing is to some extent a response to changing needs, preferences, and consumer behavior [1]. "Green" marketing differs from traditional marketing in that it focuses on environmental issues and provision of consumers with ecologically safe products. "Green" marketing encompasses a broad range of activities, including product modifications, change of production process, packaging and advertising. The concept of "green" marketing is linked to the concepts of sustainable development [2,3], ecological production and social responsibility of business [4].

\footnotetext{
* Corresponding author: valis007@mail.ru
} 
The essential characteristics, directions and problems, as well as factors and conditions for organic agriculture development are studied in the papers of such scientists as Altieri M., Haas R., Koohafkan P., Meixner O., Perevoshchikova Y., Sarkar A.N., Shcherbakova A., etc. Organic (ecological) agriculture is a production system that combines traditional practices of agriculture with modern technologies aimed at supporting soil fertility, preserving ecosystems and biological diversity $[5,6]$. The main characteristics of organic agriculture include environmental protection, use of natural and environmentally friendly substances for growing crops, activities related to preservation of natural resources, biological diversity of plants and animals, transparency of production processes and so on.

The concept of "green" marketing emerged in the 1980s in America as part of the study of issues related to environmental and social responsibility of companies as well as sustainable development, that is, such social, economic, environmental, and cultural development that would ensure the satisfaction of basic needs of both current generation and future generations of people [2, 7]. In 1975, the American Marketing Association (AMA) published the first definition of "green" marketing, introducing it as marketing of products that are presumed to be environmentally safe [1]. The concept of "green" marketing intends to integrate classic marketing elements with the management of modern environmental issues. From this perspective "green" marketing can be determined as the process of identifying, forecasting and meeting the needs of society while ensuring profits for the company and environmental protection [8].

The key aspect of "green" marketing is considered to include the focus on environmental protection in terms of reducing the negative impact of food producers on the environment and improving the quality of life of consumers [9, 10]. Activities in the field of environmental marketing can be related to the characteristics of company's products, packaging, practices of production, distribution and promotion of products.

\section{Materials and methods}

The Russian organic market, in comparison with markets of western countries, is in its early stages of development. However, the market has shown considerable growth over the last 20 years (the annual market growth rate is $20-30 \%$ ). The area of agricultural land for organic farming amounted to 855 thousand hectares in 2018 in Russia [11]. The main factors influencing the development of organic market in Russia include promotion of a healthy lifestyle and consumption of organically grown food, distrust of genetically modified foods, etc. The use of pesticides, antibiotics, genetically modified products, growth hormones, chemical fertilizers and food additives is prohibited in organic agriculture, which increases consumer interest in organic food.

There is a significant potential for the development of organic food market in Russia due to large areas of unused land and other factors [5]. The National Organic Union was established in 2013 to promote the development of organic agriculture in Russia, which includes the leading players of the Russian market of organic agricultural products: "Agranta", "Agrarnyie sistemnyie technologii", "Azbuka vkusa", "Arivera", "Organic". The legal framework of organic agriculture in Russia is determined by a number of regulatory documents. In particular, Federal Law No. 280-FZ "On organic products and on amendments in certain legislative acts of the Russian Federation" was enacted in 2020. At present, Russia has the interstate standard GOST 33980-2016 "Organic products. Regulations for production, processing, labeling and sale", national state standards GOST R 57022-2016 "Organic products. The procedure for voluntary certification of organic production" and GOST R 56104-2014 "Organic food products. Terms and definitions".

According to the National Organic Union, about 390 thousand hectares of land for organic agriculture and 134 thousand hectares for organic wild crops were certified at the 
end of 2018 in Russia. A significant number of certified land areas demonstrates a high potential for organic agriculture development in the country. However, this market segment is at an early stage of development, since the current number of certified organic agricultural producers in Russia is about 90 companies. Additionally, about 50-60 companies are at the stage of conversion. Meanwhile, the demand for organic products is growing rapidly, creating the need for more organic food producers [12].

The present study is based on a survey of representatives of marketing departments of 47 agricultural organizations functioning in the Southern Federal District, conducted from 12 to 29 September 2020. The survey was conducted using online survey tools, namely Google Forms. The Southern Federal District is located in the south of the Russian Federation. It covers an area of $447821 \mathrm{~km}^{2}(2.61 \%$ of the area of Russia). The center of this federal district is the city of Rostov-on-Don. Agriculture is one of the main economic sectors of the Southern Federal District. More than 17\% of all agricultural products of the Russian Federation are produced in this region. The district ranks third in the country in terms of the value of agricultural products, behind the Central and Volga Federal Districts. In terms of agricultural production per capita in the region, the Republic of Kalmykia occupies the leading position, the second place is taken by the Krasnodar Territory, and the Rostov Region is in the third place [11].

Survey respondents answered 15 closed and open-ended questions devoted to the activities of the companies, the issues of ecological agriculture development, state support, marketing tools used and plans for the future. The study made it possible to assess the conditions and challenges for development of "green" marketing and organic production in agricultural enterprises and farms of the region.

\section{Results}

It should be noted that among the surveyed companies $8.5 \%$ of organizations are certified organic producers, which they became in the period from 2018 to 2020 , representatives of another $7 \%$ of enterprises reported their intention to produce organic products in the future. $18 \%$ of enterprises practice elements of organic farming, but have not been certified yet. The main activities of the studied companies include the following:

- production and sale of dairy products (15\%);

- livestock, processing, production and sale of meat products $(9 \%)$;

- crop growing, grain processing, production of cereals, flour, dough for baking, etc. $(46 \%)$;

- fruit and vegetable cultivation (26\%);

- other activities (4\%).

As is known, the features of agricultural market determine marketing activity of its participants. The production of agricultural products is influenced by many factors, including location, environmental and climatic factors, seasonal nature of farming, yield fluctuations, etc. According to the survey respondents, the studied agricultural enterprises most commonly resort to production and sale cost-minimizing strategies, increase of production intensity, to the extent possible, and product diversification.

The main challenges for the development of "green" marketing and organic agriculture in the Russian agricultural sector were identified based on the results of the study using the example of Southern Federal District (Figure 1). 


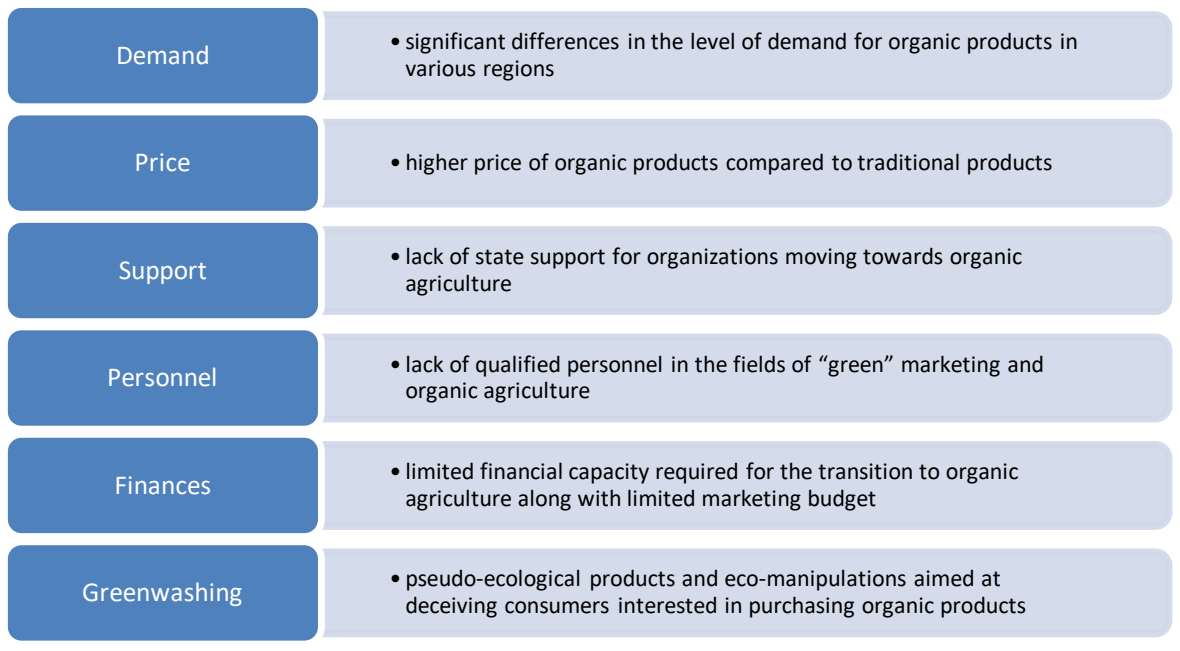

Fig. 1.The main challenges for "green" marketing use and organic agriculture development in Russian agricultural enterprises and farms (original development based on research results).

The most significant challenges for the development of organic agriculture and "green" marketing in Russian agricultural enterprises shown in Figure 1 include regional differences in the level of demand for organic products, higher price of organic products compared to traditional ones, insufficient state support for this sector (in particular, the lack of targeted programs for organic agriculture development), lack of qualified personnel, financial limits, as well as greenwashing (use of "green" marketing tools to confuse consumers as to the environmental friendliness of products and create a positive company image in order to increase sales [13]). $82 \%$ of respondents identified the increased level of risk as the main reason which stops companies from shifting to organic production.

A characteristic feature of the organic food market is that the current demand for these products generally exceeds supply. The majority of respondents emphasized that the interregional difference in the level of demand for organic products is a barrier to the development of organic agriculture in Russia. However, market research shows that organic food producers relatively less often face challenges in the sales process than traditional agricultural organizations $[14,15]$.

The price difference of environmentally friendly and traditional products mentioned by respondents as another barrier to the transition to organic agriculture is caused by such factors as:

- possible reduced crop yields in organic agriculture due to the rejection of use of chemical fertilizers and other synthetic substances in crop production;

- the more complex nature of agricultural work performed (the need to engage and pay for labour of better qualified personnel);

- underdevelopment of methods and channels for promotion of organic products in the newly established market;

- the need to allocate additional costs for environmental protection, ecological improvement, etc.

In addition to the challenges and barriers shown in Figure 1, the following problems of the development of "green" marketing and organic agriculture in Russia were identified according to the results of the research:

- insufficient public awareness of the benefits of organic products and of existing environmental issues;

- insufficient development of the legal and regulatory framework of organic agriculture; 
- lack of marketing competencies for the implementation of "green" marketing strategy of organic agricultural organization;

- a certain degree of conservatism of consumer audience (reluctance of customers to change their habits and preferences not only in terms of products purchased, their brands, quality, and characteristics, but also from the perspective of changing the usual routes, visited shops, etc.).

The research shows that most of the surveyed companies diversify their production. The preferred distribution channel for product sales in the surveyed group of agricultural producers is indirect selling through intermediaries (82\%). The goods are placed mostly in the domestic market (local, regional). $6 \%$ of the surveyed companies are engaged in exports of products to the foreign markets.

The marketing tools most commonly used by the surveyed companies were identified based on the results of the survey (Figure 2).

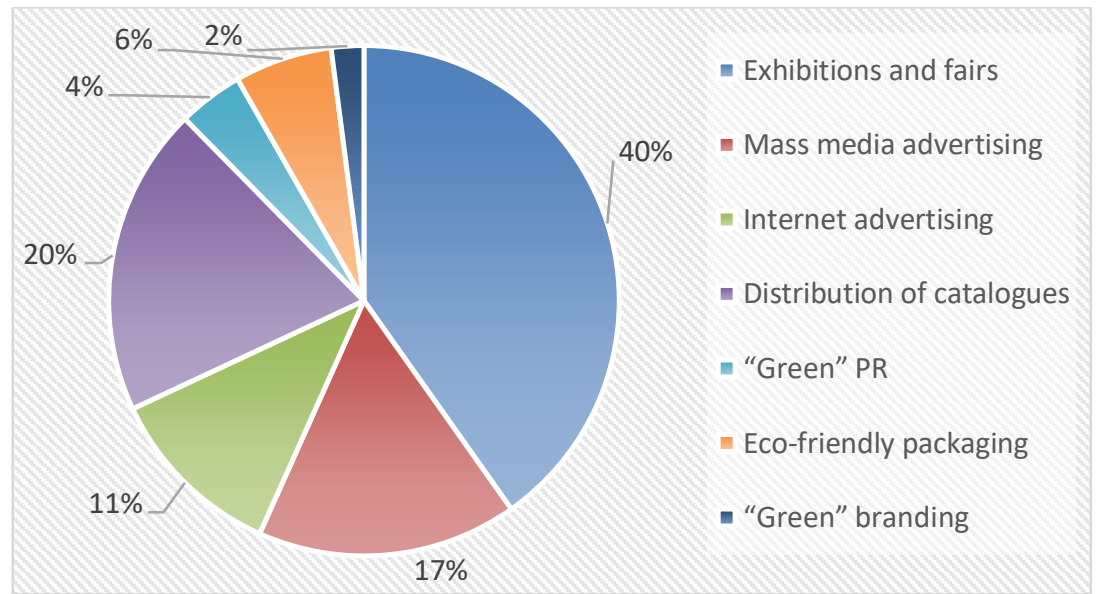

Fig.2. Marketing tools (including "green" marketing) used by the studied agricultural enterprises and farms for the period 2018-2020 (original development based on research results).

As shown in Figure 2, marketing tools most commonly used by the surveyed enterprises over the last three years include exhibitions and fairs (38\% of organizations), distribution of catalogs $(18 \%)$, advertising in the media (15\%). More than $30 \%$ of interviewed representatives of marketing departments of the surveyed agricultural organizations reported that they conduct advertising campaigns only occasionally due to the persistent demand for their products and the absence of a constant need to increase or maintain it. According to the answers of $14 \%$ of respondents, activities for promotion of the products made by the organizations they represent are carried out by intermediary companies which purchase these products for further sale. The respondents named the participation in agricultural fairs and exhibitions among the most frequently used promotion tools. "Green" branding which includes maketing activities related to connect company's brand with company's environmental values was used only by $2 \%$ of the studied organizations during the researched period. "Green" public relations intended to communicate the issues of corporate social responsibility and environmentally friendly practices of the enterprise to the public was used by $4 \%$ of the companies. Eco-friendly package made of recycled or renewable materials which are safe for humans and environment represents a component of "green" marketing strategy of $6 \%$ of researched companies. More than $40 \%$ of respondents identified the complexity and high costs of company's transition to the new marketing 
concept as the main barrier to use "green" marketing tools in activities of the studied agricultural organizations.

\section{Discussion}

The shift to organic agriculture and use of "green" marketing tools enables companies to reach target audience by offering new or improved products that can sufficiently address the needs of the given market segment. Consumers associate "green" brands with policies of environmental protection and strong business practices. Ensuring environmental friendliness of products can improve the image of producers and foster customer loyalty [16]. In this regard environmental business practices include not only the use of environmentally sound substances for the production, but also other activities aimed at protecting the environment, involving replacement of paper-based process with electronic workflow, use of products made of recycled materials, waste segregation and recycling methods, organization and conduction of environmental educational campaigns, ecopackaging, etc. $[17,18]$.

According to the results of the research conducted, agricultural organizations of the Southern Federal District rarely apply "green" marketing tools in their activities. This situation is related to the fact that organic agriculture in Russia appears to be in the early stage of development. For the transition of agricultural enterprises and farms to organic agriculture, it is necessary to overcome a number of barriers which for many organizations seem to be significant and are associated with higher business risks.

The analysis shows that at present marketing activity of these organizations is mainly focused on participation in agricultural exhibitions and fairs which is the main way of promoting agricultural products. Such an approach can be caused not only by the proven efficiency of marketing communications between producers and consumers at these traditional agricultural events, but also by avoiding using modern marketing tools (social media promotion, video content, online exhibitions, environmental marketing tools, etc.), among other things due to the lack of necessary competencies of personnel in the era of digital economy development, which creates the need to organize additional training for employees of agricultural enterprises.

Despite the complexity of companies' transition to organic production, it should be noted that such transformation can be implemented gradually, since the efficient environmental marketing strategies take into account all aspects of product life cycle and activities of organizations. Carrying out activities aimed at reducing ecosystem pollution, promoting "green" business practices, using monitoring and energy saving technologies in warehouses, developing "green" supply chains, refusing to use chemical technologies that negatively affect the environment and human health, and other similar events can contribute to the development of the "green" brand of agricultural organizations.

Implementation of "green" marketing strategy and transition to ecological production requires the adoption of the new concept by company personnel, additional financial investments, enhancement of production, sales, logistics and other processes. It appears that in order to ensure the environmental friendliness of agricultural activities, it is necessary to enhance the government support package and continue to work on the legislative framework development for organic agriculture in Russia. The experience of western countries shows the potential effectiveness of merging organic farming companies into holdings, cooperatives, and clusters. Such solutions help to raise additional funds, organize training for employees, and also reduce the risks of entrepreneurial activity.

\section{Conclusions}


"Green" marketing is one of the most important tools for achieving sustainable development, as it helps companies to focus on a long-term strategy to meet market needs while ensuring the protection of ecosystems and biological diversity. Ecological agriculture is a promising area of development for agricultural producers and the state as a whole, since it covers a unique market segment, can help increase the competitiveness and profitability of agricultural organizations, as well as contribute to the socio-economic and environmentally sustainable development of the country. It should be mentioned that despite the low rates of organic agriculture development in Russia, the domestic agricultural sector has considerable development potential, including the scientific and production base, and is capable of high performance in this area. At the same time, the implementation of "green" marketing strategy and shift to organic agriculture require significant changes of the activities of agricultural producers, and, therefore, companies need multi-faceted state support for the development of "green" strategy.

\section{Referencies}

1. M.J. Polonsky, Electronic Green Journal, 2 (1994)

2. Y.V. Teo, R. Yazdanifard, Constraints (2014)

3. M. Seretny, A. Seretny, Foundations of Management, 4 (2) (2012)

4. M. Bashir, A. Yousaf, A. Wani, Journal of Supply Chain Management Systems, 5 (2) (2016)

5. A. Shcherbakova, V Mire Nauchnych Otkrytii (World of Scientific Discoveries), 9 (4), 151-173 (2017)

6. P. Koohafkan, M. Altieri, E. Holt-Giménez, International Journal of Agricultural Sustainability, 10 (1), 61-75 (2012)

7. R. Yazdanifard, Y.K. Yan, Global Journal of Commerce \& Management Perspective, 3 (2), 33-38 (2018)

8. A.N. Sarkar, Journal of Agricultural Economics and Development, 4 (7), 105-112 (2015)

9. S.A. Bhalerao, International Journal of Development Research, 4 (8), 1757-1764 (2014)

10. D. Zaitseva, I. Krakovetskaia, Bulletin of Kemerovo State University. Series: Political, Sociological and Economic Sciences, 2, 55-60 (2016)

11. Federal State Statistics Service of Russia, available at: https://eng.gks.ru/ (accessed 20.01.2021)

12. National Organic Union of Russia, available at: http://rosorganic.ru/ (accessed 23.01.2021)

13. M. Lukinovic, L. Jovanović, Fundamental and Applied Researches in Practice of Leading Scientific Schools, 33 (3), 15-17 (2019)

14. O. Meixner, R. Haas, Y. Perevoshchikova, M. Canavari, International Journal of Food System Dynamics, 5 (2), 110-120 (2014)

15. A. Shcherbakova, Amazonian Journal of Plant Research, 2 (2), 161-174 (2018)

16. Y. Durmaz, H. Yaşar, Business and Management Studies, 2 (2), 64-71 (2016)

17. M. Lanfranchi, C. Giannetto, F. Rotondo, Journal of Corporate Responsibility and Leadership, 4 (3), 111-126 (2017) 
18. T. Zaharova, I. Krakovetskaya, Tomsk State University Journal of Economics, 42, 231245 (2018) 